Jelena Štefan*

Faculty of Philology

University of Belgrade

Ph.D. student
371.3::811.134.2'243

https://doi.org/10.18485/zivjez.2020.40.1.13

Оригинални научни рад

\title{
THE INFLUENCE OF EMOTIONS AND CURRENT MOOD ON MODAL STATEMENT: A CORPUS ANALYSIS OF THE DIALOGUE IN HENRY JAMES'S DAISY MILLER
}

Due to the fact that the conceptualization of reality and the ability of making judgments are greatly influenced by the speaker's emotions and current mood, the main aim of this research is to emphasize the effect of emotions on modal statement. The methodology entails literature review which offers an insight into the aspects of modality followed by the corpus analysis of a dialogue between the two protagonists from Daisy Miller by Henry James. It is concluded that the modal strength of modal verbs depends on the intensity of emotion.

Key words: modality, emotions, perception, discourse, modal statement.

\section{Introduction}

Due to the fact that one of the basic characteristics of the human mind is the ability to perceive elements from reality, as well as the correlations and connections between them (Lakoff \& Johnson 1999), it should be emphasized that this ability produces another important element - speculation about the probability and possibility of certain events to become realized, both in real and imaginary context, and in different aspects of time - past, present and/or future reference. Therefore, a speculation about the possible events and judgments about the perceived reality, while making a certain distance from the reality, are the two main

* jelena.stefan93@gmail.com 
domains of the category of modality. Furthermore, modal category entails speculating about the world of possible events which are not necessarily realized - the world of irealis (Kiefer 1987: 67-94). Kiefer describes the speaker's ability to speculate outside of the domain of reality while using modal expressions in both oral and written language.

Modal category presents a fruitful field for further research, especially in the domain of psycholinguistics which allows us to examine the existence of a connection between emotions and current mood with modality, in terms of the usage of particular modal expressions and verbs which correspond to the speaker's feeling at the time of utterance. The link between the speaker's emotion and his or her cognitive performance is visible in tasks such as priming and, what should be emphasized, there is a great influence of mood and emotions on speaker's confidence which results in different cognitive performance (Bolte et al. 2003: 416421).

The speaker's point of view presents a fruitful field for investigation of the unique ability to speculate. Therefore, the distance from the reality is noticeable. This is particularly visible in the literary analysis of the characters in the novel Daisy Miller by Henry James, as the characters and their relations induce certain acts and responses embodied in the abundance of modal expressions in insightful dialogues that contribute to the overall narrative. The protagonists use modal statements to express their struggle with societal rules and their effort to suppress their emotions, which is visible in the dialogues.

Upon reviewing the literature dealing with the aspect of modality and the essential aspects of the novel (character development and the uniqueness of James's narrative), the main aim of this research is to conduct a corpus analysis of the segments from the novel. The results of the analysis would provide an insight into the existence of the link between the speaker's mood and modality, since the modal expressions are used under a great emotional influence, and the correlation between the modal strength of the verb and the intensity of emotion. 


\section{Modality and emotions}

Many authors who define the term modality emphasize the same notion, common for all the definitions: the concept of modality is subjectivity, our personal attitude towards the reality surrounding us. However, even more convincing notation emphasizes the phenomenon of modality as the ultimate ability of the human mind to conceptualize even the terms belonging to the domain of antirealism for which the possibility of their actualization is subject to speculation (Kiefer 1987: 67-94). Therefore, it can be said that grammar enables us to speculate about the situations which are not necessarily real (Portner 2009: 14). This notion confirms the fact that language is nothing else but a means for expressing modality. Therefore, modality is a linguistic matter for expressing the conceptualization of the perceived elements of reality.

What should be pointed out as well is the importance of making a choice of linguistic means to express the way we perceive reality, therefore, our choice of linguistic means and the connection with the conceptualization of the terms from our immediate surroundings are the two key domains when researching modality (Nuyts 2000: 304-364).

Necessity for an event to be true and the possibility for its actualization are the base of the modality we express by making a certain distance from the perceived reality (Lyons 1977). By using a modal statement, we are the observers who simultaneously perceive and conceptualize the segments of reality based on the perception, alongside with the ability to speculate about the possible situations or "worlds" (Kiefer 1987: 71). Kiefer further introduces the theory of possible worlds in the domain of antirealism in which we can alter the conditions for the event to be actualized in order to observe all the possibilities imaginable. A statement is true only if there is a possibility for its actualization within different worlds of antirealism, given the appropriate conditions.

Epistemic modality, in fact, reflects the significance of conceptualization, thus modality is not solely linguistic, i.e. it is not based solely on linguistic choice of the modal expressions, but is 
also based on language conceptualization of the perceived stimuli from the surroundings. Also, linguistic means of modal expression and their choice actually provide an insight into the way in which we perceive and analyze the world around us (Nuyts 2000: 304364). Furthermore, in case of the epistemic modal expression or statement, the choice of linguistic means is influenced by conceptualization based on perception, which is a cause-effect type of correlation.

The proposition alone opens up the inner world of our psyche, and shows the strength of the influence of mood and emotions on perception of the segments from reality, followed by their conceptualization. We may reach the domain of antirealism through more detailed analysis of the usage of propositions or modal statements and expressions created under the influence of the speaker's emotional state, and this is achievable in the analysis of the characters' behavior in Daisy Miller. The author allows us to perceive their inner world of cognition and perception through the complex relations, in which complexity relies heavily on the emotions hidden under a thick layer of James's narrative aspects - often sarcastic modal statements in the dialogues with an aim to suppress the emotional influence.

Perhaps the most significant link between the emotions and modality in these modal statements lies in the fact that emotions present an important factor in making judgments about what is perceived. Our implicit judgments on perceived reality depend on our mood induced by a certain emotion, thus, the experimental approach concerning our reaction to the emotional factor shows that emotions affect our judgments directly by influencing our level of self-confidence which directs our future actions, such us using language to express our implicitly made decisions or formed judgments (Bolte et. al. 2003: 416-421). In the same manner, the characters in the novel are forming their judgments towards the other characters and their modal statements are emotionallyinduced. 


\section{Corpus analysis}

Probably the most significant aspect of this novel is the unique narrative enriched with character development provided through its remarkable dialogues. Not only do these dialogues present the complementary element of the overall plot of the novel, but are also a gateway for the reader to enter the world of this novel, due to the fact that it is through the analysis of these dialogues that the reader is presented with the internal world of the characters, therefore, the world of the novel itself (Salka 2013: 21-30). Before the further confirmation of these claims is presented, another aspect of this novel which needs to be further analyzed is the overall narrative and its fundamental elements - the characters (the two protagonists of the novel and their relationship) and their correlation with the overall world of social realism of the novel.

Henry James developed a complex world whose roots are placed deep in the realm of social realism (Johnson 2001). The rules of the society are the main governors of this complex reality in which the characters behave according to these rules, often hiding their true emotions in order to accommodate to the society rules. The author digs deep into the social realism by involving the clash of different cultures as a young American lady is forced to accommodate to the complex society rules in Europe - far from her home. Philip Horne refers to the tragedy of Daisy's character battling with the oppression from the society and refers to the James's own criticism towards his character accentuating the phrase "social rumpus", that is, the complex system of societal rules and behavior patterns of the 19th century (Horne 2005: 52). Daisy is, therefore, the character who had to provide a suitable response to the society that surrounds her, whilst fighting with her own emotions. It is this second clash - of emotions and society - that James perfectly depicts in the relationship between the protagonists. Daisy establishes a certain type of relationship with Mr. Winterbourne, allowing her emotions to affect her behavior and especially her utterances. Her speech throughout the novel is filled with sarcasm that protects her from the societal rules and controls her emotions that are almost 
impossible to suppress. Thence, James creates a character - Daisy whose spirit deviates from surrounding social norms and is opened to the emotions that further produce her judgments, acts and replies in valuable dialogues (Ohmann 1964: 1-11). Her deviation from the rules of society is also argued in some notable works of criticism, where it is claimed that what seems to be the most shocking and remarkable element of the novel is Daisy's freedom of spirit and liveliness, highlighted by her manner of interaction with the other characters in the novel (Johnson 2001: 41-58).

Henry James introduces the readers to the world of social realism that rests on the pillars of judgments and prejudices towards the way a young lady acts during her battle with her own emotions. Early on in the novel, Daisy becomes the victim, the fallen warrior in the battle with the reality she is trapped within the inner battle with her own feelings. Her social position in terms of class and gender additionally increases the level of her struggle (Salka 2013: 21-30). Therefore, her perception is affected to such a great extent that almost all of her utterances should be analyzed thoroughly, especially from a linguistic point of view, due to the fact that they allow us to investigate the role of modality as an emotion transmitter and at the same time - paradoxically - as a tool to hide them.

Mr. Winterbourne's utterances are also the effect of the emotions blossoming within him, but unlike Daisy, he endures the battle more easily with the strong and complex system of social realism, encouraged by his aunt, who is there to lure him back into the system whenever his emotions lead him to drift away from it (Burnside 2014). His usage of modal expressions reveal his true emotions and his unique judgments towards Daisy, and the emotions in question arise from his own amusement with the challenge he perceives in the image of Daisy. However, his modal statements show his politeness as a product of years of adhering to well-mannerism and as a way to distance himself from the reality he resides in and therefore, cease the emotional effect of his own battle, thus allowing him to resort to his cold manner with which he deals with his meetings with Daisy. Winterbourne is a survivor in 
the world of social norms as the tragic ending of the novel doesn't seem to leave a heavy burden on his emotions. It can be argued that he is left untouched by the "genuine human warmth that Daisy offers him" (Wood 1977: 34). This would mean that he remaines a winner in the domain of social realism, simultaneously having been defeated in the domain outside the system, the domain of true emotions and warmth.

Finally, Daisy ends up being the victim, a typical character portrayed as theloserin the battle with the society and another, raging battle within. This type of novel ending is typically characterized as conventional - the ending in which some characters are rewarded and some punished (Brooks 1992: 262). James therefore allows the readers to observe the absurd efforts of Daisy to overcome the societal rules, and he places the essence of her struggle in her dialogues with Winterbourne, where he doesn't create the sweet and tender expressions of love and passion, but the strong, sarcastic, cold expressions that are left for the dedicated reader to unmask and reveal raging battle with emotions underneath. In order to do so, the reader needs to be fully immersed:

Our lives are ceaselessly intertwined with narrative, with the stories that we tell and hear told... We live immersed in narrative, recounting and reassessing the meaning of our past actions... (Brooks 1992: 3)

It is, therefore, the immersion in the narrative that presents the basis of this analysis. By observing the world of narrative as a certain type of reality within which the characters give a response to the influential society in which they live through their emotions expressed in a separate way - through the relationship with other characters. Thence, the existence of different layers of the narrative can be observed as a separate world of antirealism depicting all the possibilities and probabilities emerging from the characters' mind and affecting the whole narrative through emotionally-induced modal expressions (Salka 2013: 21-30). The only way for the reader to comprehend these inner layers of the James's narrative is through the characters' expressions of emotions and logic through 
modality, the suitable language tool for reviving the internal struggle of the characters as they battle with the societal rules and respond to them in their own, individual manner.

Social realism as the starting point in numerous critics of James's work, carries the basic explanation for the behavior and emotional response of the characters in the novel, especially Daisy (Horne 2005: 46-53). The emotions that the characters express are nothing else but the reaction to the societal norms that define the lives of the characters, thus the corpus of the novel can be considered a fruitful field for the investigation of the emotional influence which becomes obvious to the readers only when it is transformed into a modal expression that dominates over the dialogues in the novel

\subsection{Modal statements and dialogues}

Daisy Miller by Henry James comprises a plethora of dialogues between the protagonists. They allow us to get an insight into the protagonists' emotional status and current mood, so that their inner, implicit world becomes available to the reader. This is especially true for the inner worlds of Daisy and Lord Winterbourne, whose dialogues reveal their hidden desires, ambiguity, soft sarcasm, humor... All these elements, if you will, stem from their mood which is under a great effect of a single emotion - love.

Love, as a complicated emotion, is often less obvious in speech as it may be hidden within a modal expression, and the true meaning and aim of the protagonist's utterance may remain unrevealed - the desire to flirt, to reveal the suppressed feeling of love. Taking these notions into consideration, it is possible to reach the protagonists' inner world of perception and speculate about their perception of the possibilities of fulfilling the above mentioned desire, as well as establishing their love relationship.

\subsubsection{Examples}

The following utterances are the extracted segments from the novel and, more precisely, from the dialogues between the two main protagonists Daisy and Winterbourne. They contain the expressions 
of love hidden under the mask of other, easily noticeable emotions and sarcasm. What follows is the analysis of the utterances in terms of the usage of modal verbs and modal strength they carry.

(1) Winterbourne: I'm afraid your mother doesn't approve of my walking with you.

Winterbourne, by successfully preserving his cold manner of interaction, distances from reality by expressing his opinion openly, to be more precise, he expresses his anxiety due to the possibility of not being allowed to walk with Daisy. His implicit attitude towards reality (which is greatly affected by the feeling of the desire to successfully overcome the challenge of winning Daisy's heart) surfaces through the phrase I'm afraid. By using this expression, it is obvious that, although it is weak in terms of its meaning, it reveals rather high intensity of emotions directing the usage of modal expressions. Therefore, Winterbourne automatically combines his good manners, politeness and tendency to express his opinion within the phrase I'm afraid, an introductory phrase which allows his suppressed judgments influenced by his true desire to become visible to the readers who are able to unmask them. This phrase is therefore observed as a modal statement: it allows the speaker to distance from the reality and prepares the overall utterance for the expression of a judgmental form. Moreover, it reveals the very feelings and desires it is supposed to suppress, hence the paradox.

(2) Daisy: Well, Mr. Winterbourne, I think you're horrid!

This expression shows that the emphasis is on the main verb think bearing a modal meaning. By using it, Daisy distances from reality and her flirtation is achieved by her insult and criticism of Winterbourne (e.g., using the adjective horrid, meaning cruel, terrifying), and it is well-known to the readers that this adjective isn't a product of her authentic opinion about Winterbourne. Her free spirit is driven by her emotions (love and passion) and while she aims to express her anger, the verb of perception to think serves as a tool for expressing her modal judgment which is there to hide her underlying intentions. The intensity of the insult equals the intensity of her emotions towards Winterbourne. 
(3) Daisy: You might have come to see me!

Winterbourne: I arrived only yesterday.

Daisy: I don't believe that!

In this instance, it is possible to notice the gradual enhancement of the emotional factor concerning modal expressions in the dialogue. First of all, Daisy's statement “(...) you might have come to see me", which is both modal and exclamative, suggests her strong wish to be the very reason for Winterbourne's visit. Even though the actual verb might is weak in terms of the potential of the modal strength it carries, the distance she makes from the reality is significantly big due to the strong emotion.

(4) Winterbourne: I certainly shall not help you to find him.

Daisy: Then I shall find him without you.

Winterbourne: You certainly won't leave me!

Here, it is also possible to notice the rise of the emotional influence through speakers' choice of modal expressions. To be precise, what can be noticed is the protagonists' usage of modal verbs shall, shall not which result in the culmination in Winterbourne's statement. His statement reveals his true feelings for Daisy, and his mood is rather imperative. Daisy shows her inner state as well, through stubbornness, and she expresses her strong attitude in the conversation by using modal verbs in the negative form (shall not), showing her strong feelings which inspired the usage of these modals. Modal verbs, such as shall, are the result of a very strong emotion, hidden under the veil of stubbornness and irony.

(5) Winterbourne: I think you have made a mistake. You should sometimes listen to a gentleman - the right one? (...) No, he's not the right one.

In this example, although the modal strength of the verb should is weakened by the adverb sometimes as a result of sarcasm, it reveals Winterbourne's true emotion - the desire for Daisy. The correlation between the modal and emotional intensity becomes obvious - lower probability of "listening to a gentleman" he proposes in his utterance is inspired by the higher intensity of the emotion in question. 
(6) Daisy: It's a pity these rooms are so small; we can't dance! Winterbourne: I am not sorry we can't dance, I don't dance. Daisy: Of course you don't dance, you're too stiff. I hope you enjoyed your drive with Mrs. Walker.

These utterances reflect Daisy's current mood - she is jealous. The statement I hope you enjoyed your drive with Mrs. Walker contains sarcasm which shows her jealousy. Verb can't wasn't used in this statement just to express the impossibility of dancing but to express her own disability to honestly show her feelings. Therefore, negative forms of the verbs can and $d o$ are caused by the intense emotion.

(7) Winterbourne: I am afraid your habits are those of a flirt (...) but I wish you would flirt with me and me only.

As it has already been shown in example (1), the modal expression I'm afraid presents a distance from reality, and the weaker the modal verb's potential, the bigger the distance from reality is. The expression I wish you would is an example of a low level of modal strength but inspired by a high-intensity emotion.

(8) Winterbourne: Though you may be flirting, Mr. Giovanelli is not.

Although the verb may belongs to the group of modal verbs that express low probability (Lyons 1977), in fact, it stands as a reflection of the highest probability concerning Daisy's flirting. Winterbourne is well-aware of the fact that she is flirting, but uses this verb as a result of emotional influence. Verb may, therefore, reveals his sarcasm, induced by his unfulfilled desire, and although it is not the verb expressing the highest level of probability, but exactly the opposite, as it suppresses the high intensity of his emotions. Therefore, the highest level of emotion intensity is hidden by a lowprobability expression carried by the weakest modal verb.

(9) Daisy: Well, I should think you would be lonesome!

Daisy uses a very strong expression in correlation with the emotions causing it. She appears to be angry, but all that anger is a product of a hidden emotion - love, which results in the usage of a strong modal phrase - "I should think" with an exclamation. 
(10) Winterbourne: I believe that it makes very little difference whether you're engaged or not.

This expression presents the greatest influence of emotions on a modal statement. It is because Winterbourne's emotions affect his choice of expressions - verb believe, above all, which creates a distance, but which carries a low level of probability. It does make a difference to him, but his choice of the modal reveals his emotions.

Table 1. Corpus analysis of the dialogues (Daisy and Winterbourne)

\begin{tabular}{|c|c|c|c|}
\hline $\begin{array}{c}\text { Dialogue } \\
\text { number }\end{array}$ & Modal statement & $\begin{array}{l}\text { Discourse } \\
\text { meaning }\end{array}$ & $\begin{array}{l}\text { Underlying } \\
\text { meaning }\end{array}$ \\
\hline 1 & I'm afraid & $\begin{array}{l}\text { politeness, } \\
\text { modal phrase }\end{array}$ & $\begin{array}{l}\text { strong desire, } \\
\text { great concern }\end{array}$ \\
\hline 2 & I think you're horrid & $\begin{array}{l}\text { anger, } \\
\text { annoyance }\end{array}$ & $\begin{array}{l}\text { strong desire, love, } \\
\text { passion }\end{array}$ \\
\hline 3 & You might have come & $\begin{array}{l}\text { low probability, } \\
\text { sarcasm }\end{array}$ & desire, flirtation \\
\hline 4 & $\begin{array}{l}\text { Shall (not) - both } \\
\text { characters }\end{array}$ & $\begin{array}{l}\text { stubborness, } \\
\text { irony }\end{array}$ & $\begin{array}{l}\text { fear of rejection } \\
\text { driven by high- } \\
\text { intensity emotions }\end{array}$ \\
\hline 5 & should & advice & irony \\
\hline 6 & $\begin{array}{l}\text { I hope you enjoyed } \\
\text { your drive... }\end{array}$ & sarcasm & jealousy \\
\hline 7 & $\begin{array}{l}\text { I wish you would flirt } \\
\text { with me }\end{array}$ & $\begin{array}{l}\text { wish, desire, } \\
\text { honesty }\end{array}$ & love, desire \\
\hline 8 & may & low probability & $\begin{array}{l}\text { high level of } \\
\text { probability, desire, } \\
\text { passion, sarcasm }\end{array}$ \\
\hline 9 & I should think & $\begin{array}{l}\text { modal phrase, } \\
\text { expressing } \\
\text { opinion }\end{array}$ & anger and passion \\
\hline 10 & I believe & $\begin{array}{l}\text { expressing } \\
\text { opinion }\end{array}$ & irony \\
\hline
\end{tabular}


An overview of the analyzed modal statements from the dialogues is shown in the Table 1. As it can be observed, Daisy's usage of modal statements is in correlation with her character strong emotions are inducing the presence of sarcasm and anger expressions in her statements. It perfectly reflects the freedom of her spirit, liveliness and true emotions that reside in her soul.

On the other hand, Winterbourne's statements contain more sarcasm, reaching irony underneath the layers of his main desire and passion to seduce and win Daisy's heart. His statements reflect his character - he is polite, well-behaved, but also sarcastic because, unlike Daisy, he is not driven by true feelings, but rather by his desire to meet the challenge of winning in the short-term love game with Daisy. As John Burnside argues, he is "untouched by anything save his own contrived narrative" (Burnside 2014).

However, both Daisy's and Winterbourne's modal expressions prove that their discourse meanings are used as a tool to express completely different form of modal logic and judgments - lowprobability modal verbs express a high level of probability perceived by the characters, while being influenced by a high-intensity emotion. The higher the intensity of the emotion and the probability of a certain event perceived, the weaker the illocutionary force in discourse.

\section{Conclusion}

What can be concluded from the corpus analysis is that all the analyzed dialogues show the nature of the connection between emotions and modals - the weaker the probability or the modal strength the verb entails, the stronger the emotion.

Modal statement reflects speaker's ability to perceive reality and form judgments. In literature, it is a crucial tool for presenting the thoughts of a character. Therefore, it can be said that modality connects perception and conceptualization of the elements from our surroundings, alongside with speculating about the probability of actualization of an event not only in reality. What is even more important is the fact that the speaker's emotional state and the 
experienced mood at the time of using modal expression in speech plays a vital role in the choice of modals to be used.

Corpus analysis showed how the modal strength of the modal verbs depends on the intensity of emotions - the stronger emotion, the greater modal strength as well as the speaker's distance from the reality. Hence, modal statement may be observed as one of the most powerful tools in speech due to its dual function: it expresses perception and conceptualization of reality and shows the uniqueness of human mind when influenced by emotions and/or mood. The complexity of the relationship between the characters in the novel is the product of the emotions and is equal to the complex system of discourse in the novel in which the characters express their unique perception of the reality. Therefore, the analyzed dialogues are nothing but a complex system on its own, ruled by the social realism that the novel is based on, whilst the antirealism is reached through the representations of the characters' internal world and also through their emotionally-induced dialogues.

The novel itself is based on the aforementioned social realism comprising the complex structure of character relations governed by societal norms. The clash of two different cultures emerges as a separate motif, enabling the complexity of the narrative system. All these influences lead to the emotional response which is not always evident, as it is one of the main aspects to James's narrative. The emotions are, therefore, hidden while still having a dominant position in producing a modal judgement of the character. It even directs the communication in the novel, encouraging the readers to reveal the source of their utterances underneath the "mask" - sarcasm combined with pride and often anxiety masks the underlying source emotions - love, passion, desire. All of these communication phenomena are brought to life within a modal statement. Finally, readers are offered with quite a challenge - to reveal the paradoxical relation between modal verbs and expressions in terms of probability expressed and the characters' judgments affected by the underlying emotions. 


\section{BIBLIOGRAPHY}

Bolte et al. 2003: A. Bolte, T. Goschke, J. Kuhl, Emotion and intuition: Effects of positive and negative mood on implicit judgments of semantic coherence. Psychological Science, 14(5), 416-421.

Brooks 1992: P. Brooks, Reading for the plot: Design and intention in narrative. Harvard University Press.

Burnside 2014: J. Burnside, John Burnside's Book of a Lifetime: Daisy Miller by Henry James. In: Independent. Online, [https://www.independent. co.uk/arts-entertainment/books/reviews/john-burnside-s-booklifetime-daisy-miller-henry-james-9112815.html]

Horne 2005: P. Horne, The biography of Daisy Miller. In: K. C. Reed \& P. G. Beidler (eds.), Approaches to teaching Henry James's Daisy Miller and The turn of the screw, Modern Langauge Association, 46-53.

James 1963: H. James, Daisy Miller. Penguin Modern Classics.

Johnson 2001: L. Johnson, Daisy Miller: Cowboy Feminist. The Henry James Review, 22(1), 41-58.

Kiefer 1987: F. Kiefer, On defining Modality. Folia Linguistica, 20(1), 67-94. Lakoff \& Johnson 1999: G. Lakoff, M. Johnson, Philosophy in the Flesh. New York: New York Publishers.

Lyons 1977: J. Lyons, Semantics, vol.2. Cambridge: Cambridge University Press.

Nuyts 2000: J. Nuyts, Epistemic modality, language and conceptualization. Amsterdam/Philadelphia: John Benjamin's Publishing Company.

Ohmann 1964: C. Ohmann, Daisy Miller: A Study of Changing Intentions. American Literature, 36(1), 1-11.

Portner 2009: P. Portner, Modality. Oxford University: Oxford Linguistics. Salka 2013: Y. M. Salka, The patriarchal society's responses to Daisy Miller's performances in James' Daisy Miller. Unpublished thesis. Yogyakarta: Yogyakarta State University, Faculty of Languages and Arts.

Wood 1977: C. Wood, Frederick Winterbourne, James's Prisoner of Chillon. Studies in the Novel, 9(1), 33-45. 


\section{Jelena Štefan}

\section{UTICAJ EMOCIJA I TRENUTNOG RASPOLOŽENJA NA MODALNI ISKAZ: KORPUSNA ANALIZA DIJALOGA U ROMANU DEJZI MILER HENRIJA DŽEJMSA}

\section{Rezime}

Primarni cilj ovog rada jeste da se ispita uticaj emocija i trenutnog raspoloženja govornika na njegov modalni iskaz. Metodologija obuhvata pregled relevantne literature koja pruža uvid u osnove modalnosti i uticaja koje emocije imaju na kogniciju i upotrebu jezika, kao i korpusnu analizu dijaloga romana Dejzi Miler Henrija Džejmsa. Zaključeno je da jačina modalnog glagola zavisi od jačine emocija u trenutku iskaza.

Ključne reči: modalnost, emocije, percepcija, diskurs, modalni iskaz. 